\title{
IDENTIFIKASI KANDUNGAN FORMALIN PADA BAHAN PANGAN (MIE BASAH, BANDENG SEGAR DAN PRESTO, IKAN ASIN, TAHU) DI PASAR GEDE KOTA SURAKARTA
}

\section{Rezania Asyfiradayati ${ }^{1 *}$, Artika Ningtyas ${ }^{2}$, Madani Lizansari ${ }^{3}$, Yuyun Purwati ${ }^{4}$, Winarsih $^{5}$}

\author{
1,2,3,4,5 Program Studi Kesehatan Masyarakat Fakultas Ilmu Kesehatan Universitas \\ Muhammadiyah Surakarta. Jl. A. Yani, Pabelan, Kartasura, Surakarta. \\ Email: ${ }^{1}$ rezaniaasyfiradayati@ums.ac.id, ${ }^{2}$ artikaningtyas@gmail.com \\ ${ }^{3}$ madanilizansari24@gmail.com, 4 yuyunpurwa05@gmail.com, \\ 5 winnarasih1616@gmail.com
}

\begin{abstract}
Abstrak
Formalin merupakan bahan tambahan pangan yang dilarang berdasarkan Peraturan Menteri Kesehatan Republik Indonesia Nomor 722/MenKes/Per/IX/1988, sehingga kandungannya dalam produk makanan harus negatif. Jika kadar formalin yang terkandung dalam bahan pangan tersebut melewati nilai ambang batas aman, maka akan dapat berakibat toksis. Tujuan dari penelitian ini adalah untuk mengetahui kandungan formalin dalam bahan pangan (mie basah, bandeng segar dan presto, ikan asin, tahu) yang dijual di Pasar Gede Kota Surakarta. Penentuan kandungan formalin menggunakan Uji kualitatif (Uji Teskit). Penetapan kadar formalin menggunakan metode Uji Kualitatif (Uji Asisi-Alkalimetri). Hasil penelitian ini menunjukkan bahwa 2 sampel mie basah, 1 sampel ikan bandeng segar dan presto, 5 ikan asin, dan 4 tahu positif formalin dengan kadar tertinggi tertinggi sebesar 0,0278ppm pada ikan asin. Sehingga dapat disimpulkan bahwa bahan pangan yang diperdagangkan di Wilayah kota Surakarta belum semuanya mematuhi Peraturan Menteri Kesehatan Republik Indonesia Nomor 722/MenKes/Per/IX/1988 kandungan formalin dalam makanan harus 0 atau negatif. Sehingga perlu dilakukan penelitian bahan tambahan makanan lain (misal boraks dan pewarna) yang digunakan dalam bahan pangan lain yang dipasarkan di Surakarta serta masyarakat perlu segera diberikan informasi tentang keamanan makanan yang dikonsumsi.
\end{abstract}

Kata kunci: Bahan pangan, formalin, pasar.

\begin{abstract}
Formalin is a prohibited food additives according to Regulation of the Minister of Health of the Republic of Indonesia Number 722 / Menkes / Per / IX / 1988, so its content in food products must be negative. If the content of formalin contained in the foodstuff passes the value of safe threshold, resulting in toxic. The purpose of this research was to know the content and content of formalin in food (wet noodles, fresh milkfish and presto, salted fish, tofu) which were sold in Pasar Gede Surakarta. Determination of formalin content was using qualitative
\end{abstract}


test (Test Teskit). Determination of formalin content was using Qualitative Test method (Assay-Alkalimetry Test). The results of this study indicated that 2 samples of wet noodles, 1 sample of fresh milkfish and presto, 5 salted fish, and 4 tofu formalin positive, with the highest level of 0.0278 ppm was found in salted fish.

Keywords: foodstuff, formalin, market.

\section{PENDAHULUAN}

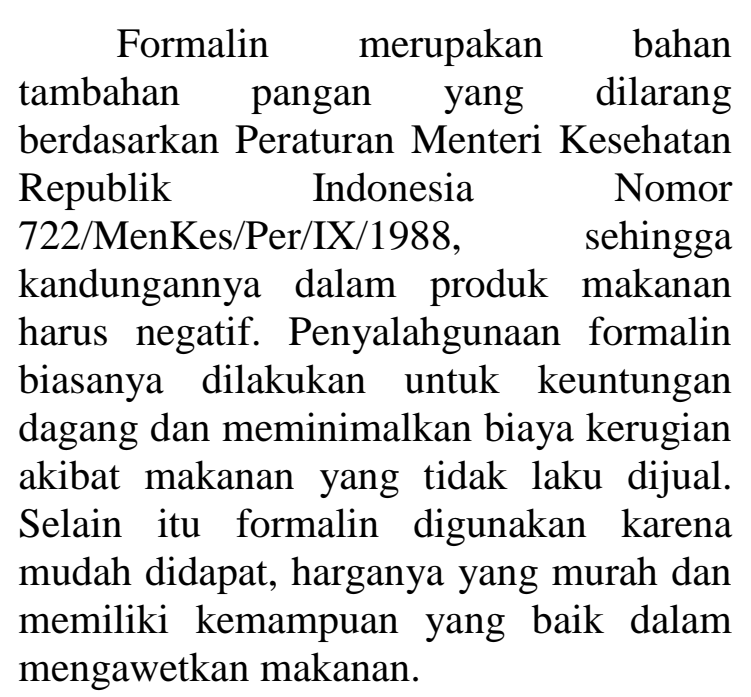

Pedagang atau produsen menambahkan formalin dengan tujuan agar ikan asin tahan lebih lama. Selain itu keberadaan formalin lebih murah dan mudah untuk didapatkan (Abdullah, 2013). Pemakaian formalin dalam makanan dapat menyebabkan timbulnya efek akut dan kronik yang dapat menyerang saluran pernapasan, pencernaan, sakit kepala, hipotensi (tekanan darah tinggi), kejang, tidak sadar hingga koma. Selain itu, juga dapat terjadi kerusakan hati, jantung, otak, limpa, pankreas, sistem susunan syaraf, pusat dan ginjal.

Berbagai bahan pangan yang banyak digemari masyarakat seperti, mie basah, tahu, ikan asin, ikan bandeng ditemukan banyak mengandung formalin. Berdasarkan hasil sampling dan pengujian laboratorium BPOM Desember 2017 yang dilakukan secara serial dan serentak di beberapa daerah Indonesia menunjukan sebanyak $34,55 \%$ tahu, $64,32 \%$ mie basah, 6,36\% ikan mengandung formalin. Hasil sidak keamanan pangan yang dilakukan BPOM Semarang di Pasar Gede Kota Surakarta pada bulan Juni 2017 menunjukan 2 sampel mie basah, 2 jenis ikan asin dan 1 bandeng segar positif formalin, (BPOM, 2017).

Pasar Gede Kota Surakarta merupakan salah satu pasar induk yang digunakan sebagai tempat pengambilan dagangan bahan pangan oleh pedagangpedagang di pasar tradisonal Kota Surakarta lainnya serta menjadi pasar rujukan masyarakat di wilayah Surakarta maupun di luar Surakarta. Berdasarkan hal tersebut, peneliti ingin mengetahui keberadaan formalin dalam bahan pangan mie basah, ikan asin, bandeng segar dan bandeng presto di Pasar Tradisonal Surakarta.

\section{METODE PENELITIAN}

Penelitian ini dilakukan dengan menggunakan metode penelitian deskriptif dengan pendekatan cross sectional. Penelitian ini menggunakan teknik purposive sampling yakni pengujian dilakukan pada mie basah jenis bulat dan gepeng, tahu, ikan bandeng presto dan bandeng segar, ikan asin jenis peda, jambal roti, pakang, teri nasi yang dijual di Pasar Gede, sertahu tahu krempel dan tahu kotak.

Penentuan kandungan formalin menggunakan uji kualitatif (uji tes kit) untuk mendeteksi ada tidaknya formalin pada sampel dilanjutkan uji kuantitatif (uji Asidi-Alkalimetri) untuk mengetahui kadar formalin. Instrumen dalam 
penelitian ini meliputi Tes kit, Gelas Ukur, Sendok, Botol Uji, Neraca Timbang, Labu Erlenmeyer $100 \mathrm{ml}$, Hot Plate, Buret, Statif, Pipet Tetes, Gelas Kimia.

Adapun pelaksanaan penelitian dengan menggunakan tes kit, dilanjutkan dengan uji Asidi-Alkalimetri diuraikan sebagai berikut:

1. Uji Kualitatif (Uji Tes Kit): Sampel dilakukan penghalusan, ditimbang sebanyak $10 \mathrm{~g}$, Ditambahkan air panas sebanyak $20 \mathrm{ml}$ dan diaduk kemudian dibiarkan dingin. Air campuran diambil $5 \mathrm{ml}$ kemudian ditetesi dengan menggunakan Reagen A dan B masingmasing sebanyak 4 tetes, dikocok dan dibiarkan selama 10 menit. Apabila sampel positif formalin, maka warna cairan berubah menjadi merah muda.

2. Uji Kuantitatif (Uji Asidi-Alkalimetri) (Farmakope, 1997) : Sampel yang sudah dihaluskan ditimbang sebanyak \pm 3 gram dimasukkan ke dalam labu elemeyer, menambahkan $25 \mathrm{ml}$ hidrogen peroksida encer dan $50 \mathrm{ml}$ natrium hidroksida $1 \mathrm{~N}$, sampel dipanaskan di atas hot plate hingga mendidih. Ditambahkan 2 tetes larutan fenolftalein sampai terjadi perubahan warna menjadi merah muda. Menitrasi sampel dengan asam klorida 0,1 N sampai warna merah muda memudar menjadi bening. Hasil titrasi dicatat volumenya, setiap sampel di lakukan pengulangan sebanyak tiga kali. Melakukan perhitungan kandungan formalin dan menghitung rata-rata kandungan formalin:

Kandungan formalin $=\frac{\mathrm{ml} \mathrm{HCl} \times \text { N HCl x 30,03 }}{\mathrm{w}(\mathrm{mg})}$ $\sum$ formalin $=\frac{\mathrm{kf} 1+\mathrm{kf} 2+\mathrm{kf} 3}{3}$

\section{HASIL DAN PEMBAHASAN}

Peneliti melakukan pengambilan sampel mie basah, ikan asin, dan ikan bandeng, tahu di Pasar Gede Kota Surakarta pada bulan Juni 2018. Empat sampel mie basah diambil dari dua pedagang dimana pedagang mempoduksi sendiri mie basahnya. Sampel Ikan bandeng diambil dari dua pedagang dimana pemasok ikan pada masingmasing pedagang berbeda. Sampel ikan bandeng terdiri dari 5 ikan bandeng segar dan 2 ikan bandeng presto. Sedangkan sampel ikan asin yang digunakan sebanyak 4 jenis ikan asin yang diambil dari pedagang dari produsen berbeda wilayah. Sampel tahu diambil 2 jenis yaitu tahu kotak dan krempel pada 2 pedagang di Pasar Gede. Seluruh sampel dilakukan pengujian di laboratorium kimia Universitas Muhammadiyah Surakarta. Data yang diperoleh dipaparkan sebagai berikut:

Tabel 1. Hasil Uji Kualitatif dan Kuantitatif Mie Basah

\begin{tabular}{lccccc}
\hline Kode Sampel & $\begin{array}{c}\text { Kandungan } \\
\text { Formalin }\end{array}$ & \multicolumn{5}{c}{ Angka Kandungan Formalin (ppm) } & \multirow{2}{*}{$\sum$ Formalin } \\
\cline { 3 - 5 } & & $\mathbf{1}$ & $\mathbf{2}$ & $\mathbf{3}$ & \\
\hline MBBPG 1 & - & 0 & 0 & 0 & 0 \\
MBGPG 1 & - & 0 & 0 & 0 & 0 \\
MBBPG 2 & + & 0,0035 & 0,0035 & 0,0040 & 0,0037 \\
MBGPG 2 & + & 0,0065 & 0,0066 & 0,0066 & 0,0066 \\
\hline
\end{tabular}


Tabel 2. Hasil Uji Kualitatif dan Kuantitatif Ikan Bandeng Segar dan Presto

\begin{tabular}{llllll}
\hline Kode Sampel & Kandungan & \multicolumn{3}{c}{ Angka Kandungan Formalin (ppm) } & \multirow{2}{*}{ Formalin } \\
\cline { 3 - 5 } & & \multicolumn{4}{c}{ Pengulangan } \\
\cline { 3 - 5 } & & \multicolumn{1}{c}{$\mathbf{1}$} & $\mathbf{2}$ & $\mathbf{3}$ \\
\hline IBS 1 & Positif & 0,0060 & 0,0080 & 0,0055 & 0,0065 \\
IBS 2 & Negatif & 0 & 0 & 0 & 0 \\
IBP 1 & Positif & 0,0105 & 0,0156 & 0,0126 & 0,013 \\
IBP 2 & Negati & 0 & 0 & 0 & 0 \\
IBP 3 & Negatif & 0 & 0 & 0 & 0 \\
IBP 4 & Negatif & 0 & 0 & 0 & 0 \\
IBP 5 & Negatif & 0 & 0 & 0 & 0 \\
IBP 6 & Negatif & 0 & 0 & 0 & 0 \\
\hline
\end{tabular}

Tabel 3. Hasil Uji Kualitatif dan Kuantitatif Ikan Asin

\begin{tabular}{|c|c|c|c|c|c|}
\hline \multirow[t]{3}{*}{ Kode Sampel } & \multirow{3}{*}{$\begin{array}{c}\text { Kandungan } \\
\text { Formalin }\end{array}$} & \multicolumn{3}{|c|}{ Angka Kandungan Formalin (ppm) } & \multirow[t]{3}{*}{$\sum$ Formalin } \\
\hline & & \multicolumn{3}{|c|}{$\begin{array}{l}\text { Pengulangan } \\
\end{array}$} & \\
\hline & & 1 & 2 & 3 & \\
\hline IAJ 1 & Positif & 0,0198 & 0,0207 & 0,0200 & 0,0201 \\
\hline IAP 1 & Positif & 0,0170 & 0,0158 & 0,0160 & 0,0162 \\
\hline IAPK 1 & Negatif & 0 & 0 & 0 & 0 \\
\hline IATN 1 & Negatif & 0 & 0 & 0 & 0 \\
\hline IAJ 2 & Positif & 0,0260 & 0,0290 & 0,0285 & 0,0278 \\
\hline IAP 2 & Positif & 0,0120 & 0,0145 & 0,0200 & 0,0155 \\
\hline IAPK 2 & Negatif & 0 & 0 & 0 & 0 \\
\hline IATN 2 & Positif & 0,0170 & 0,0180 & 0,0180 & 0,0053 \\
\hline
\end{tabular}

Tabel 4. Uji Kualitatif dan Kuantitatif Tahu

\begin{tabular}{cccccc}
\hline \multirow{2}{*}{ Kode Sampel } & \multirow{2}{*}{$\begin{array}{c}\text { Kandungan } \\
\text { Formalin }\end{array}$} & \multicolumn{3}{c}{ Angka Kadar Formalin (ppm) } & \multirow{2}{*}{ PFormalin } \\
\cline { 3 - 5 } & & $\mathbf{1}$ & $\mathbf{2}$ & $\mathbf{3}$ & \\
\hline PGA 1 & Positif & 0,0018 & 0,0018 & 0,0017 & 0,0018 \\
PGA 2 & Positif & 0,0054 & 0,0055 & 0,0055 & 0,0055 \\
PGB 1 & Positif & 0,0020 & 0,0021 & 0,0020 & 0,0020 \\
PGB 2 & Positif & 0,0040 & 0,0032 & 0,0048 & 0,0040 \\
\hline
\end{tabular}

Metode uji kualitatif tes kit menggunakan Easy Test, metode uji ini menggunakan prinsip perubahan warna. Tes kit uji residu formalin jenis ini untuk mendeteksi adanya residu formalin dengan sensitifitas 0,001-2 ppm. (BBP4BKP, 2011). Hasil uji kualitatif formalin dengan menggunakan uji tes kit menunjukkan dari 4 sampel mie basah yang diuji sebanyak 2 sampel positif formalin, 2 sampel ikan bandeng positif formalin meliputi 1 ikan bandeng presto dan 1 ikan bandeng segar, 5 sampel ikan asin positif formalin serta 4 sampel tahu positif formalin, hal ini dibuktikan dengan terjadinya perubahan warna cairan menjadi merah muda setelah ditetesi dengan reagent $\mathrm{A}$ dan reagent $\mathrm{B}$.

Sampel positif formalin dilanjutkan uji kuantitatif menggunakan titrasi asidi alkalimetri. Sampel yang positif mengalami perubahan warna menjadi merah muda setelah ditetesi indikator fenolftealin, sehingga dilakukan titrasi 
menggunakan larutan $\mathrm{HCl}$ untuk mencapai ekuivalen dan dapat diketahui kandungan formalinnya. Berdasarkan hasil uji kuantitatif kandungan formalin pada mie basah bulat 2 (MBBPG 2) dan gepeng 2 (MBGPG 2) diperoleh rata-rata kandungan formalin sebesar 0,0037 dan 0,0066 ppm sedangkan rata-rata kandungan formalin ikan bandeng segar dan ikan bandeng presto di Pasar Gede Kota Surakarta diperoleh rata-rata kandungan formalin pada Ikan Bandeng Segar 1 (IBS 1) sebesar 0,0065 ppm, dan pada Ikan Bandeng Presto 1 (IBP 1) sebesar 0,013 ppm. Pada sampel ikan asin terdapat 5 jenis ikan asin yang positif formalin yaitu 2 ikan asin jambal roti (IAJ 1 dengan kadar 0,0201 ppm dan IAJ 2 dengan kadar 0,0278 ppm), 2 jenis ikan asin peda putih (IAP 1 dengan kadar $0,0162 \mathrm{ppm}$ dan IAP 2 dengan kadar 0,0155 ppm), sedangkan ikan asin teri nasi (IATN 2 dengan kadar 0,153 ppm). Pada sampel tahu terdapat 4 sampel yang positif mengandung formalin, 2 jenis tahu dari Pasar Gede A (PGA 1 dengan kadar 0,0018 ppm dan PGA2 dengan kadar 0,0055 ppm), 2 jenis tahu dari Pasar Gede B (PGB 1 dengan kadar 0,0020 ppm dan PGB 2 dengan kadar 0,0040 ppm).

Hasil Kandungan formalin tertinggi sebesar 0,0278 ppm. Meskipun demikian hal tersebut masih di anggap tidak benar karena dalam Peraturan Menteri Kesehatan Republik Indonesia Nomor 722/MenKes/Per/IX/1988 kandungan formalin dalam makanan harus 0 atau negatif. Kadar formalin yang digunakan produsen sebagai pengawet dalam berbagai olahan pangan relatif samam hal ini dapat disebabkan oleh beberapa faktor diantaranya produsen mempunyai takaran yang relatif sama (dalam jumlah kecil) dalam menambahkan formalin pada bahan pangan, dimana takaran tersebut berpengaruh terhadap keawetan pangan namun tidak mempengaruhi rasa.
Mie basah positif formalin antara lain jenis bulat dan gepeng yang diambil pada pedagang 2 , dimana pedagang juga merupakan produsen. Produsen 2 memproduksi mie basah dalam jumlah yang banyak, menurut pengamatan peneliti mie basah yang dijual tidak habis dalam satu hari, sehingga dapat menjadi faktor yang menyebabkan produsen menambahkan formalin agar mie basah yang di produksi tetap awet. Sedangkan berdasarkan hasil observasi peneliti mie basah pada pedagang 1 habis terjual setiap hari, sehingga sejalan dengan hasil penelitian yakni tidak ditemukan adanya formalin pada sampel yang di ambil.

Ikan bandeng segar positif formalin berasal dari Semarang sedangkan ikan bandeng presto berasal dari Banyuanyar. Jauhnya jarak tempuh pengiriman menjadi alasan produsen untuk menambahkan formalin. Pada ikan bandeng segar yang sudah mati mudah mengalami pembusukan, karena ikan bandeng memiliki kandungan air yang banyak disebagian tubuhnya dan tidak mudah bertahan lama di lingkungan pasar. Selain itu kondisi ikan yang sudah mati, akan mudah mengalami reaksi yang dipengaruh suhu ruangan yang tidak mendukung dan cahaya maupun mikroorganisme yang mempercepat pembusukan. Ketika terjadi pembusukan, maka akan nampak kondisi fisik ikan bandeng yang tidak segar lagi.

Kandungan formalin ikan asin jambal roti paling tinggi dibandingkan ikan asin jenis lainya. Menurut Santoso (2008), ikan asin jambal roti dalam tahap pengeringan sangat lama mengingat dagingnya yang tebal sehingga proses pengasinan akan membutuhkan waktu yang semakin lama dan garam yang lebih banyak, jika pengeringan tidak sempurna maka ikan asin jambal roti mudah hancur dan mudah membusuk, sehingga produsen menambahkan formalin untuk mempercepat pengeringan dan memperpanjang umur simpan, sama 
halnya dengan ikan asin jenis peda putih sama-sama memiliki daging yang tebal sehingga memiliki proses pengasinan yang sama dengan ikan asin jambal roti. Penelitian serupa telah dilakukan oleh Hastuti (2010) telah melakukan penelitian kandungan formalin pada ikan asin yang diambil dari beberapa pasar tradisional di wilayah Madura meliputi Pasar Kamal, Pasar Socah, Pasar Bangkalan, dan salah satu Pasar di Sampang dengan hasil sampel ikan asin yang diambil dari salah satu Pasar di Sampang memiliki kadar formalin cukup tinggi, yaitu $44.14 \mathrm{mg} / \mathrm{kg}$.

Tahu yang positif mengandung formalin berasal dari Pasar Gede berasal dari pedagang A dan B. Formalin digunakan pada tahu karena tahu merupakan makana yang bergizi tinggi dan makanan basah serta cepat sekali membusuk (Effendy, 2012). Penggunaan formalin pada tahu disebabkan kondisi tahu yang hanya dapat bertahan selama 2 hari saja jika tanpa formalin, akan tetapi tahu dapat bertahan lebih lama jika ditambahkan formalin yaitu 5 sampai satu minggu.

Menurut peneliti selain hal di atas penambahan formalin pada bahan pangan dapat terjadi karena kurangnya pengawasan dari Dinas Kesehatan setempat dan BPOM serta tingkat pengetahuan yang kurang dari produsen tentang bahaya penggunaan bahan pengawet berupa formalin untuk mie basah. Penyalahgunaan formalin dilakukan produsen untuk keuntungan dagang dan meminimalkan biaya kerugian akibat makanan yang tidak laku dijual. Adapun penjual mie basah yang beperan sebagai distributor atau mengambil barang dagangannya pada produsen tidak tahu menahui mengenai penambahan formalin pada mie basah.

Terdapat beberapa dampak negatif terhadap kesehatan manusia akibat dari mengkonsumsi makanan yang mengandung formalin, diantaranya menurut Saparinto (2006), efek samping penggunaan formalin tidak secara langsung akan terlihat. Efek ini hanya terlihat secara kumulatif, kecuali jika seseorang mengalami keracunan formalin dengan dosis tinggi. Dalam kadar yang sangat tinggi formalin bisa menyebabkan kegagalan peredaran darah yang bermuara pada kematian.

Di dalam tubuh, jika terakumulasi dalam jumlah besar, formalin merupakan bahan beracun dan berbahaya bagi kesehatan manusia. Jika kandungan dalam tubuh tinggi, akan bereaksi secara kimia dengan hampir semua zat di dalam sel sehingga dapat menyebabkan berbagai keluhan, misalnya iritasi lambung dan kulit, muntah, diare, serta alergi. Bahkan bisa menyebabkan kanker, karena formalin bersifat karsinogenik (Wispriyono, 2006).

Menurut Arumsari (2017), upaya pengendalian yang dapat dilakukan terhadap kandungan formalin yang terdapat pada makanan yang dijual dipasaran adalah perlu dilakukanya tindakan oleh BPOM untuk melakukan peninjauan kembali ke pasar-pasar untuk melakukan uji formalin pada ikan asin yang dijual oleh pedagang dan menindaklanjuti penyalahgunaan formalin yang terjadi. Selain itu juga diharapkan adanya penyuluhan-penyuluhan kepada para pedagang dan produsen mengenai larangan penggunanaan formalin pada ikan asin.

Menurut ACGIH (American Conference of Governmental and Industrial Hygienists) menetapkan ambang batas aman formalin dalam tubuh adalah $0,4 \mathrm{ppm}$. Dalam penelitian didapatkan kadar formalin tertinggi sampel yaitu 0,0278 ppm, maka berdasarkan batas toleransi formalin pada sampel ikan asin masih dapat diterima oleh tubuh dalam 1 hari, sampel ikan asin yang diuji masih dalam kategori aman untuk dikonsumsi. Meskipun demikian hal 
tersebut di anggap tidak benar karena dalam Peraturan Menteri Kesehatan Republik Indonesia Nomor 722/MenKes/Per/IX/1988 kandungan formalin dalam makanan harus 0 atau negatif.

\section{KESIMPULAN}

1. Dalam bahan pangan yang diperdagangkan di Pasar Gede Kota Surakarta terdapat 9 sampel yang mengandung formalin dimana kadarnya berbeda-beda, rata-rata kadar formalin berkisar 0,017 ppm - 0,0278 ppm.

2. Bahan pangan yang diperdagangkan di Wilayah kota Surakarta belum semuanya mematuhi Peraturan Menteri Kesehatan Republik Indonesia Nomor 722/MenKes/Per/IX/1988 kandungan formalin dalam makanan harus 0 atau negatif.

\section{SARAN}

1. Perlu dilakukan penelitian bahan tambahan makanan lain (misal boraks dan pewarna) yang digunakan dalam bahan pangan lain yang dipasarkan di Surakarta.

2. Masyarakat perlu segera diberikan informasi tentang keamanan makanan yang dikonsumsi.

\section{DAFTAR PUSTAKA}

Abdullah. (2011). Pengawetan Pangan. UI Press, Jakarta.

Alsuhendra \& Ridawati. (2013). Bahan Toksik dalam Makanan. Rosda, Jakarta.

Arumsari, G. (2017). Perilaku Penggunaan Formalin Pada Pedagang dan Produsen Mie Basah dan Tahu di Provinsi Dki Jakarta. Jurnal Kesehatan Masyarakat Andalas. Universitas Andalas : Program Studi S-1 Kesehatan Masyarakat Fakultas Kesehatan Masyarakat Universitas Andalas.

BBP4BKP. (2011). Test Kit Untuk Uji Residu Formalin. Balai Besar Penelitian dan Pengembangan Pengolahan Produk dan Bioteknologi Kelautan dan Perikanan, Jakarta.

BPOM. (2017). Data Hasil Sidak Keamanan Pangan BPOM Semarang Di Pasar Gede Surakarta Juli 2017.

Efendy. (2004). Penggunaan Bahan Tambahan Makanan. Media Indonesia, Jakarta.

Farmakope Indonesia Edisi III. (1997). Departemen Kesehatan Republik Indonesia.

Hastuti, S. (2010). Analisis kualitatif dan kuantitatif formaldehid pada ikan asin di Madura. Jurnal Agrointek. Vol 4, No. 2 Agustus 2010 Hal 132-137.

Peraturan Menteri Kesehatan RI No. 722/Menkes/Per/IX/1988. (1998). Tentang Bahan Tambahan Pangan.

Santoso, H. (2008). Kandungan Formalin Ikan Asin. Kanisius, Yogyakarta.

Saparitno, C. \& Hidayati, D. (2006). Bahan tambahan pangan. Kanisius, Yogyakarta.

Wispriyono. (2006). Formalin. Penerbit Trubus Agrisarana, Surabaya. 